\title{
Effects of gap area and shape on recolonization by grassland plants with differing reproductive strategies
}

Post-print/Accepted manuscript

Peter M. Kotanen

Kotanen PM. 1997. Effects of gap area and shape on recolonization by grassland plants with differing reproductive strategies. Can. J. Bot. 75: 352-361 doi:10.1139/b97-037

\section{HOW TO CITE TSPACE ITEMS}

Always cite the published version, so the author(s) will receive recognition through services that track citation counts, e.g. Scopus. If you need to cite the page number of the TSpace version (original manuscript or accepted manuscript) because you cannot access the published version, then cite the TSpace version in addition to the published version using the permanent URI (handle) found on the record page. 
July 26, 1996

BOT 96-130

\title{
Effects of gap area and shape on recolonization by grassland plants with differing reproductive strategies
}

\author{
Peter M. Kotanen ${ }^{1}$ \\ Department of Integrative Biology, University of California, Berkeley, CA 94720, USA
}

Address for Correspondence

Until September 1:

Rangeland Ecosystem Science, NR 206, Colorado State University, Fort Collins, CO 80523, USA

Telephone: 970-897-2210

FAX: 970-491-2339

e-mail: pmklda@pondside.uchicago.edu

After September 1:

Department of Botany, Erindale College, University of Toronto, 3359 Mississauga Road North, Mississauga, Ontario L5L 1C6, Canada.

e-mail:pmklda@pondside.uchicago.edu

\footnotetext{
${ }^{1}$ Current Address : Department of Botany, Erindale College, University of Toronto, 3359 Mississauga Road North, Mississauga, Ontario L5L 1C6, Canada.
} 


\begin{abstract}
Species with poor dispersal ability initially should be slower to colonize larger or rounder gaps than smaller or less circular gaps. Conversely, dispersive and seedbanking species should be less sensitive than poor dispersers to gap size and shape, and less confined near a gap’s edges. I tested these ideas with a 3-year experiment in which I monitored the revegetation of gaps in grassland vegetation. Initially, species reproducing largely by clonal growth (bulbs and perennial graminoids) were the most sensitive to gap size and (to a lesser extent) shape, reaching their greatest abundances in small and/or rectangular openings. Species relying on seed dispersal (annual grasses) also tended to do best in smaller plots, but were less concentrated near plots’ edges. Species relying on seed dormancy (dicots and Juncus bufonius) were least sensitive to plot size, shape, and distance from an edge. In subsequent years, these patterns often were obscured or reversed, reflecting continuing seed immigration and environmental and competitive conditions within gaps. These results indicate that species respond to gap size and shape in ways consistent with their reproductive biologies, and suggest that the importance of gaps’ dimensions may vary among plant communities.

Key words: disturbance, gap shape, gap size, grasslands, revegetation, succession.
\end{abstract}




\section{Introduction}

Disturbance-created gaps are important to the diversity and structure of many biological communities (White 1979; Sousa 1984a; Pickett and White 1985; Hobbs and Huenneke 1992). Gaps provide opportunities for regeneration, afford habitat for species which are competitively inferior or have environmental requirements not met in undisturbed areas, and add spatial heterogeneity to otherwise homogeneous landscapes. Intertidal boulder fields (Sousa 1979a, 1979b, 1980), grasslands (Platt 1975; Collins and Glenn 1988), and forests (Connell 1978; Hartshorn 1980; Platt and Strong 1989) are among the many systems which owe much of their character to their regimes of gap creation and closure.

The revegetation of a newly-created gap initially should be influenced by the gap’s size and shape (Sousa 1984a, Pickett and White 1985). Since most of the area of a small gap is close to an edge, such a gap should be recolonized rapidly by clonal ingrowth and by the short-range dispersal of propagules from immediately adjacent vegetation. In contrast, revegetation of larger gaps should be slower and more strongly dominated by species with good seed dispersal ability, while poor dispersers remained confined near the gap's edges (Connell and Slatyer 1977; Miller 1982; Sousa 1984a). Similarly, compared with gaps of other shapes, circular gaps should be colonized more slowly and less by clonal ingrowth and short-range dispersal, since circles have the minimal perimeter : area ratio and the maximal proportion of surface distant from any edge (Miller 1982; Sousa 1984a, 1985). These arguments also imply that the importance of gap size and shape may depend, in part, on the reproductive strategy of the species under consideration: species dependent on clonal encroachment should be affected more strongly by gap size, shape, and the distance from the nearest edge than species with better dispersal ability or capable of surviving disturbance.

Grasslands and oldfields have proven especially tractable for studies of smallscale gap dynamics (Platt 1975, Platt and Weis 1977, Gross 1980; Gross and Werner 
1982; Hobbs and Mooney 1985; Marks and Mohler 1985; Rabinowitz and Rapp 1985;

Rapp and Rabinowitz 1985; Belsky 1986a, 1986b; Goldberg and Gross 1988; Coffin and Lauenroth 1989; Peart 1989a, 1989b; Parish and Turkington 1990a, 1990b; Belsky 1992; Bergelson et al. 1993; Arnthórsdóttir 1994; Bullock et al. 1994, Lavorel et al. 1994; Aguilera and Lauenroth 1995; Bullock et al. 1995; Burke and Grime 1996). In this paper, I discuss the results of an experiment in which I assessed the importance of gap size and shape for the early stages of recolonization by a variety of grassland plants. I found that plot area and shape were important, and that their effects were strongly dependent upon the dispersal and life history characteristics of the invading plants. Initially, largely clonal species tended to be more sensitive to plot area, shape, and the distance from an edge than were dispersive species and seed bankers. Over time, these effects gradually were eclipsed by both seed immigration and within-plot processes. My results also suggest that the effects of gap area and shape may differ significantly among systems which differ floristically. 


\section{Methods}

\section{Study site}

I conducted this study in the White House Meadow of the Angelo Preserve of the University of California (123 37' W, 39 45' N), about 240 km north of San Francisco. This meadow is one of a series of natural openings in Douglas Fir (Pseudotsuga menziesii ${ }^{2}$ ) - Redwood (Sequoia sempervirens) forest. It probably once was occupied by perennial-dominated Coastal Prairie, but as is true of most Californian grasslands (Heady 1988; Heady et al. 1988; Sims 1988; Heady et al. 1992), it has been greatly altered by the invasion of Eurasian annual grasses. Currently, both the appearance and the biomass of this meadow are dominated by native perennial graminoids (here defined as Gramineae, Cyperaceae, and Juncaceae), primarily the bunchgrass Danthonia californica; however, annual grasses (mostly exotics) including Aira caryophyllea, Bromus hordaceus, Briza minor, and Vulpia spp. also are abundant. Native perennial Liliaceae and Amaryllidaceae (hereafter "bulbs") are common, while numerous herbaceous dicots (forbs) occur infrequently. As a result of modern suppression methods, fire currently is unimportant at this location, but soil disturbances created by animals play a significant role in structuring the local vegetation (Kotanen 1994a, 1994b, 1995): between 1990 and 1993, more than $7 \%$ of the surface area of 5 major meadows at the Angelo Preserve annually was disturbed by feral pigs, Sus scrofa, pocket gophers, Thomomys bottae, and moles, Scapanus latimanus (Kotanen 1995). Additional information on this site may be found in Johnson (1979) and Kotanen (1994a, 1994b, 1995).

\footnotetext{
2 Nomenclature follows Hickman (1993).
} 


\section{Experimental methods}

In February of 1991, I created 45 plots, evenly spaced in an approximately $10 \mathrm{~m} \times 10 \mathrm{~m}$ grid. I left five plots undisturbed as controls, while I excavated the remaining plots to a depth of $9 \mathrm{~cm}$ (below the principal root and bulb zone), removing most pre-existing vegetation. Half of these gaps were circular, divided equally among 4 sizes. Each size represented a fourfold increase in area over the last $\left(156,625,2500\right.$, and $10000 \mathrm{~cm}^{2}$ : treatments $\mathrm{C} 1, \mathrm{C} 4, \mathrm{C} 16, \mathrm{C} 64)$. The remaining gaps were $1: 4$ rectangles, with areas again ranging in fourfold steps between 156 and $10000 \mathrm{~cm}^{2}$ (R1, R4, R16, R64). Plots were randomly allocated among treatments.

The principal data I collected were the numbers of living and/or reproductive shoots rooted in a square $10 \mathrm{~cm} \times 10 \mathrm{~cm}$ quadrat centred in each plot. The smallest rectangular plots were the only exception: since these measured only $6.25 \mathrm{~cm} \times 25 \mathrm{~cm}$, I instead examined a $100 \mathrm{~cm}^{2}$ area of the floor of these plots. In order to investigate whether revegetation varied with respect to distance from a gap’s edge, I also sampled a $10 \mathrm{~cm} \times 10 \mathrm{~cm}$ quadrat next to a random edge of the two largest sizes of plots. Each year, I performed the primary sampling in June (Table 1), after most species had flowered but while early spring annuals still were readily identifiable; however, I sampled bulbs 3-4 months earlier (Table 1) because their shoots withered and disappeared by June. I did not sample bulbs in 1991, since few remained visible by the initial sampling.

Counting shoots acknowledges the modular nature of plant construction and avoids the problem of identifying individuals in a complex sward, but does not necessarily reflect biomass. In particular, though local species of annual graminoids resemble one another in size, they are much smaller than perennial graminoids or bulbs: the dry mass of a shoot of Danthonia is more than 10 times that of a shoot of Aira. $\underline{\text { Seed and bulb banks }}$ 
In order to describe the component of revegetation not resulting from immigration, I assayed the seed and bulb banks using soil cores. At 2-3 month intervals over a 21 month period, I took $3.7 \mathrm{~cm}$ diameter cores from 5 random locations within the experiment, and then subdivided each into $2 \mathrm{~cm}$ thick slices. The depths I sampled were 0 - $2 \mathrm{~cm}$ (including seeds from the soil surface), 2-4 cm, 4-6 cm, and 8-10 cm. The sampling depth extended $1 \mathrm{~cm}$ deeper that the depth of the experimental plots, both because it is difficult to excavate a plot without somewhat disturbing and exposing the underlying soil, and because laboratory trials indicated that some local species (e.g., Bromus spp.) could successfully germinate despite burial beneath $\sim 1 \mathrm{~cm}$ of soil. I removed roots and bulbs from each slice, which I then broke up and placed on a bed of sterile sand in a $5 \mathrm{~cm}$ pot. I incubated these pots with abundant water in a growth chamber with a day-night cycle of $14 \mathrm{~h}: 10 \mathrm{~h}$ and a daily temperature cycle averaging $25 \mathrm{C}: 10 \mathrm{C}$. I counted emergent seedlings after 2 months; examinations during waterings indicated very few seedlings $(<1 \%)$ died before this final date.

I designed these methods to provide a standardized index of those seeds competent for rapid germination (Gross 1990), and therefore capable of immediately exploiting a new soil disturbance. Although different species can differ dramatically in their germination requirements (Harper 1977; Fenner 1985; Baskin and Baskin 1989; Fenner 1992), there are three reasons that these methods should have provided a reasonable estimate of this readily germinable component of the seed bank. First, the temperature regime fell within the limits expected in spring and fall (Johnson 1979), when most germination normally occurs in the field, while the light cycle corresponded to the beginning of May. Second, since the core samples were field-collected, the seeds they contained were pre-exposed to germination requirements (e.g., scarification, freezing) not available in the laboratory. Third, lab trials indicated that most of the species which dominate this system germinate readily, given sufficient moisture. 


\section{Seed dispersal}

I constructed seed traps by placing disks of filter paper coated with the adhesive Tangletrap (The Tanglefoot Company, Grand Rapids, Michigan, USA) in the lower halves of 5 $\mathrm{cm}$ diameter petri dishes, and covering each trap with $1 \mathrm{~cm}$ wire mesh to exclude rodents and birds. In April of 1991, I permanently anchored 10 such traps to the ground surface at random locations within the experiment. At 1-2 month intervals for 20 months, I placed fresh filter paper in each trap. After approximately 2 weeks, I removed this paper and counted trapped seeds. Hobbs and Mooney (1985) found that seed losses from similar traps were negligible.

\section{Analysis of data}

The "functional group" approach has proven useful in understanding the effects of disturbance on plant communities (McIntyre et al. 1995). In the present paper, I have taken an analogous approach, combining plants into four "species groups" united by similar life history (annual vs. perennial), dispersal mode (seed vs. vegetative), and / or morphology (graminoid vs. forb). These groups are: (1) annual graminoids, (2) perennial graminoids, (3) perennial bulbs, and (4) dicots. I used these groups because they simplifed analysis while emphasizing reproductive and life history differences.

I used repeated-measures fixed effects ANOVAs to assess the effects of disturbance size and shape (Kirk 1982). Plot size and shape were considered fixed factors because they were deliberately selected; date was considered fixed because there is no reason to believe that the years of this experiment represented a random sample of Californian weather (Kirk 1982; Bennington and Thayne 1994). I did not include the undisturbed controls in these analyses, but I have presented their results for purposes of comparison; elsewhere, I have discussed other experiments designed to quantify differences between disturbed and undisturbed communities (Kotanen 1994a, 1995, in 
press, unpublished). In order to stabilize variances, I log-transformed all data before analysis (Cochran's C: $0.05>\mathrm{p}>0.01$ for 1 ANOVA; $\mathrm{p}>0.05$ in the remainder). 


\section{Results}

The colonizing flora

The vegetation of most plots was dominated by bulbs in spring, and by graminoids in summer (Fig. 1); the remainder of this paper will particularly emphasize these groups. Dicots ( 15 spp.) were comparatively scarce (Fig. 1). A single Pseudotsuga seedling was the only vascular plant observed which did not fall into any of the species groups used; this individual was omitted from all analyses.

All observed bulbs were Dichelostemma capitatum or (rarely) closely-related species of Brodiaea and Triteleia, while all perennial graminoids sampled in disturbed plots were either Danthonia californica or (increasingly) Luzula comosa (Table 2). The most abundant annual graminoids in the principal (central) quadrats of disturbed plots were Juncus bufonius and Aira caryophyllea; Briza minor, Vulpia spp., and Bromus hordaceus contributed the remainder (Table 2). However, the relative abundances of these species changed markedly over time. In particular, Aira rapidly increased from initial rarity to exceed Juncus both in abundance and in the strength of its correlation with annual graminoids as a whole (Table 2).

In contrast with other experiments at this location (Kotanen 1994a), redisturbance by moles and pocket gophers was rare: only four plots (an R1, R4, R16, and a control) were so disturbed. These plots were not treated differently in the analyses, because (1) disturbance by fossorial animals is a natural, "background" process normally expected to interact with other disturbances at this location (2) the effects of such redisturbance generally are mild (Kotanen in press), (3) their exclusion did not substantially alter the results, and (4) their treatment as a separate factor would have led to an excessively complicated design.

Effects of gap size and shape (central quadrats) 
Gap shape had significant effects for only one group: bulbs were more common in rectangular gaps than in circular gaps (Fig. 1; Table 3). Gap size had significant overall effects on the density of bulbs, perennial graminoids and dicots, but not on the density of annual graminoids (Table 3). Bulbs were consistently more common in smaller gaps than in the larger ones (Fig. 1; Table 3); however, for the remaining species groups, significant year $\times$ size interactions suggested that the results should be broken down by sampling date. These datewise analyses indicated that perennial graminoids were significantly affected by plot size in 1991 and 1992 (Dunn-Íidák corrected $\mathrm{p}<0.05$ on each date: smaller plots contained more shoots), but these effects were non-significant in 1993. Numbers of annual graminoids and dicots were significantly affected by plot size only in 1993 ( $\mathrm{p}<0.05)$, but these groups exhibited opposite trends: annual graminoids were more common in smaller plots, while dicots were more common in larger plots.

When annual graminoids were partitioned into Juncus bufonius and annual grasses per se, the results changed (Fig. 2; Table 4). In this case, overall tests detected a significant effect of plot size (for Juncus) and of both plot size and shape (for annual grasses), as well as significant interactions involving the year of sampling. When results were subdivided by year, significant effects of plot size (Dunn-Íidák corrected $\mathrm{p}<0.05$ ) were detected in 1992 and 1993 for both Juncus and annual grasses. However, these two groups responded in opposite directions: Juncus was more common in larger plots, while annual grasses were more common in smaller plots (Fig. 2).

\section{$\underline{\text { Plot centres vs. edges }}$}

Most species groups initially tended to be at least as common near plots' edges as at their centres, but this pattern often changed over time (Fig. 3); consequently, analyses were split by year. Perennial graminoids were more common near plots’ edges in 1991, as were bulbs in 1992, but were more common in plots’ centres by the following year (paired ttests; Dunn-liidák p<0.05). Dicots, annual graminoids, and annual grasses never differed 
significantly with respect to quadrat position, but Juncus bufonius was more common in plots’ centres in 1993 (paired t-tests; Dunn-Íidák p<0.05).

$\underline{\text { Soil seed and bulb banks }}$

The size of the seed bank reached a maximum in late summer and a minimum in winter; numbers of bulbs were less variable (Fig. 4). Seedlings of at least 8 species were observed (Table 5), but the active component of the seed bank was dominated numerically by annual graminoids (67\% of all seedlings germinated); Aira caryophyllea alone contributed $44 \%$ of all seedlings, while Juncus bufonius contributed 22\%. Dicots (3 spp.) were very scarce, contributing only $2 \%$ of all seedlings. While bulbs were abundant $(0.63$ per $\mathrm{cm}^{2}$ ), no seedlings of bulb-bearing species were detected.

Both bulbs and seeds declined rapidly in numbers with depth (Table 5); as a result, the bias produced by not sampling the entire soil column was small. While bulbs, Aira, and Juncus were found in the deepest samples, $82 \%$ of the active seed bank and $89 \%$ of bulbs were located less than $4 \mathrm{~cm}$ from the soil surface (Table 5). Only Juncus bufonius was evenly distributed with respect to depth (48\% deeper than $4 \mathrm{~cm}$ ). 


\section{$\underline{\text { Seed dispersal }}$}

Seed dispersal was highly seasonal, with the total number of seeds trapped peaking from late May to June (Fig. 4). Seeds of 8 species were trapped. Annual graminoids comprised $65 \%$ of the estimated total seed rain: Aira caryophyllea alone comprised 32\%, while Juncus bufonius contributed 26\%; Bromus hordaceus and Vulpia spp. each contributed $<5 \%$. Luzula subsessilis was the most common perennial graminoid (27\% of the seed rain) followed by Danthonia californica (6\%) and Holcus lanatus $(<1 \%)$. Seeds of only one dicot (Eremocarpus setigerus) were captured (1\% of the seed rain), while no seeds of bulb-bearing species were detected. Danthonia is likely to have been underrepresented, since some of its seeds are produced by cleistogamous flowers and dispersed with disarticulating culms (Crampton 1974; Campbell et al. 1984), which are too large to enter a seed trap; the bias against most other species should have been small, since most produced small dispersules at heights well above the 1-cm rim of the traps. 


\section{Discussion}

\section{Gap size and shape}

Studies from habitats as diverse as forests (Denslow 1980; Runkle 1982; Brokaw 1985;

Platt and Strong 1989; Phillips and Shure 1990), the rocky intertidal (Paine and Levin 1981; Sousa 1984b), old-fields (Davis and Cantlon 1969; Reader and Buck 1991), and grasslands (Coffin and Lauenroth 1989; Arnthórsdóttir 1994; Bullock et al. 1995; Burke

and Grime 1996) have shown that a gap's size may have important effects on succession. I also found gap area to have significant effects; gap shape was much less important. As expected, these results were not the same for all species groups. Initially, those groups dominated by species able to survive disturbance (deep seed bankers) or with abundant seed dispersal (annual grasses) were less sensitive to gap size, shape, and/or distance to plots' edges than groups whose members relied wholly or partly on clonal ingrowth (perennial graminoids, bulbs). In subsequent years, these initial patterns often were obscured or even reversed, probably reflecting responses to environmental and competitive conditions within gaps.

There are several explanations for the relatively small effects of gap shape. First, while gap diameters varied 8-fold and gap areas varied 64-fold, perimeter length and perimeter : area ratio varied only 1.4-fold between rectangular and circular gaps of the same area. Second, while the distance from the centre of a gap to the nearest edge was smaller for a rectangular gap than for a circular gap of the same area, the distance to the furthest edge was increased. As a result, almost half (49.4\%) of each rectangle's perimeter was more remote from its centre than was true for the corresponding circular gap (thanks to $\mathrm{M}$. Weis for pointing this out). These calculations suggest that the effects of gap shape may have been underestimated by measurements taken near gaps' centres; edge vs. centre contrasts may be more sensitive indicators of the importance of gap shape or perimeter. 


\section{$\underline{\text { Arrival of colonists }}$}

The strong initial effects of gap size and shape on the abundance of bulbs might be expected from the manner in which these species migrate into disturbed plots. The locally common bulbs produce few seeds, and are practically absent from the seed rain (Kotanen 1994a), but produce large numbers of vegetative bulblets, in some cases at the ends of subterranean runners (Hickman 1993; Kotanen 1994a, 1995). As the walls of the experimental excavations crumbled, many such bulblets were transported into these plots along with the collapsing earth. Since this could move bulblets only a few $\mathrm{cm}$, bulbs were strongly sensitive to both gap size and shape, occuring most frequently near gaps' edges and in smaller, less circular gaps.

The weaker effects of plot size and quadrat position on annual graminoids illustrate one of the problems of aggregating species into "functional" groups. "Annual graminoids" evidently comprised a heterogeneous category containing two sub-groups with distinct reproductive strategies: grasses and Juncus bufonius. The local annual grasses have shallow seed banks; as a result, they were removed from plots during their initial excavation, and recolonized primarily by seed immigration. In contrast, Juncus bufonius was common in the deeper fraction of the seed bank as well as in the seed rain. It did not depend on immigration from the surrounding undisturbed vegetation, where it is very scarce (Kotanen 1995). One consequence of this difference was that, while Juncus never was more common in smaller gaps or near edges, annual grasses declined in abundance with increasing plot size, after the first sampling. Given that annual grasses rely much more heavily on the seed rain than does Juncus, there are two reasons to expect this pattern. First, small gaps have a larger perimeter: area ratio than large gaps, probably leading to higher per-unit-area rates of seed immigration (Sousa 1984a). Second, smaller gaps probably are more sheltered from wind by the surrounding vegetation, reducing surface air velocity. As a result, a seed produced inside a small gap or deposited by 
gravity or eddy currents into its protected air is unlikely to be subsequently removed (Chambers and MacMahon 1994; Vogel 1994).

Perennial graminoids were subject to some of the same factors affecting recolonization both by bulbs and by annual grasses. Most of the locally common species (e.g., Danthonia californica, Luzula comosa) possess a "bunchgrass" morphology in which new tillers are produced very close to the parent shoot, and therefore have a very limited ability to spread clonally into a disturbed site. Consequently, like bulbs, perennial graminoids initially were most common in small plots and near plots' edges. However, like annual grasses, perennial graminoids (especially Luzula) do commonly occur in the seed rain, though rarely in the sub-surface seed bank. Immigrating seeds may have contributed to the higher numbers of perennial graminoids in smaller plots (see above), but also allowed perennials to permanently establish away from plots' walls, gradually obscuring the patterns initially produced by clonal encroachment.

The scarcity of dicots in the seed rain and their weak response to plot dimensions and quadrat position suggest that, like Juncus, many of these species also may have recruited from buried seed, but were not detected in soil cores because the correct germination cues were not provided. The local dicots include many legumes, euphorbs, and other hard-seeded species (Kotanen 1995) which may require complex germination stimuli (Harper 1977; Fenner 1985; Baskin and Baskin 1989; Fenner 1992).

\section{$\underline{\text { Later events }}$}

Initially, the revegetation of disturbed plots is likely to have been strongly limited by a scarcity of propagules (Kotanen, in press). The fact that most observed patterns of recolonization were consistent with patterns in propagule supply suggests that, at least initially, physical differences among gaps were not be strong enough to obscure immigration-driven patterns. Over time, however, the space within a newly-created opening is likely to become increasingly saturated both by the continuing influx of 
immigrants and by the growth and reproduction of successful colonists within the gaps themselves. As well, as plots revegetate, the establishment of plants in their interiors may protect them from surface air currents (Chambers and MacMahon 1994), aiding in the trapping and retention of dispersing seeds, and further accelerating revegetation. As a result, the revegetation of a gap gradually should become less strongly influenced by constraints on immigration, and more strongly controlled by environmental conditions and within-plot processes such as competition and local seed production.

Gaps differ physically from the surrounding vegetation (Kotanen unpublished). Excavated plots tend to be warmer, especially in the summer, experience more frostheave in winter, are less shaded, and are more frequently flooded. As well, because plant populations are severely reduced during gap creation, excavations initially may contain greater per-capita pools of nitrogen and water. Some of these physical conditions probably are little influenced by gap size or shape (e.g. flooding, soil nitrogen), but others may be significantly affected by gaps' dimensions. As often is the case for forest gaps (e.g., Platt and Strong 1989), physical conditions in smaller and narrower excavations probably deviate less from the physical conditions of the surrounding vegetation. For example, smaller and less circular gaps are more completely shaded by the surrounding vegetation than are larger, rounder gaps, and consequently should also experience lower temperatures, higher humidity, and possibly less frost-heave. Over time, both differences among gaps and differences between gaps and the surrounding vegetation should gradually diminish as revegetation proceeds.

Despite the short duration of this study, within-plot processes may explain why some groups gradually developed patterns of abundance opposite to those predicted from considerations of immigration alone. For example, dicots were more abundant in larger plots in 1993, and both Juncus bufonius and perennial graminoids tended to be more common in plots' centres than at their edges. These patterns probably reflect a 
performance advantage: plants often grow better or have a higher expectation of setting seed in larger gaps, in part because they are more isolated from competition with the surrounding vegetation (e.g., Goldberg and Werner 1983; McConnaughay and Bazzaz 1987, 1990; but see Burke and Grime 1996 for a counter-example).

\section{Refuges vs. gaps}

Discussions of reserve design often assume that larger and more circular habitat patches are better for the conservation of biodiversity than the converse (Simberloff 1988); discussions of disturbance and patch dynamics (Connell and Slatyer 1977; Sousa 1984a; Pickett and White 1985) suggest that smaller and less circular gaps often should be more rapidly revegetated. These views are different sides of the same coin: conservation emphasizes the stability of populations, while rapid recolonization demands that rates of population change be maximized. Large, circular gaps may extend the persistence of populations of gap-dependent species, just as large, circular forest remnants may be best for the preservation of forest species. Conversely, small, rectangular gaps may be a better choice if the goal is to increase, rather than decrease, successional rates and the immigration of near-edge species.

\section{$\underline{\text { Floristic considerations }}$}

My results emphasize that the importance of gap size and shape depend upon the reproductive strategies occurring in the local flora. If clonally spreading species are abundant, as is the case in many perennial grasslands, gaps' dimensions may strongly affect revegetation (e.g., Coffin and Lauenroth 1989; Arnthórsdóttir 1994; Bullock et al. 1995). In contrast, if seed banks, highly dispersive seeds, or survivors provide most of the colonists, then gap size and shape initially may be less important (e.g., Uhl et al. 1988; Coffin and Lauenroth 1989; Bullock et al. 1995). A corollary is that the effects of different disturbances may be similar in some systems but not in others. For example, gopher mounds (ca. $100 \mathrm{~cm}^{2}$ ) and disturbances created by feral pigs (often many $\mathrm{m}^{2}$ ) 
might be expected to support differing vegetation in highly clonal perennial grasslands, but perhaps not in dispersal-dominated annual grasslands. Lessons learned in one system may apply only in communities with similar reproductive spectra. If so, then functional classifications of reproductively diverse natural communities may be essential to our ability to adequately predict the effects of disturbance (McIntyre et al. 1995). 


\section{Acknowledgements}

I would like to thank W.P. Sousa, M.E. Power, F.S. Chapin III, R. Barrett, J. Winterer, R. Hufbauer, P. Steel, and L.D. Ambedian for support, advice, and comments on earlier drafts of this manuscript, which also was improved thanks to the comments of Michael Weis and an anonymous reviewer. Funding was provided by the Nature Conservancy of California, the University of California Natural Reserve System, an NSF Doctoral Dissertation Improvement Grant (DEB-9122821), an NSERC (Canada) PGS Fellowship, the Hardman Foundation, and the Department of Integrative Biology at U.C. Berkeley. 


\section{References}

Aguilera, M.O., and Lauenroth, W.K. 1995. Influence of gap disturbances and type of microsites on seedling establishment in Bouteloua gracilis. J. Ecol. 83: 87-97.

Arnthórsdóttir, S. 1994. Colonization of experimental patches in mown grassland. Oikos, 70: 73-79.

Baskin, J.M., and Baskin, C.C. 1989. Physiology of dormancy and germination in relation to seed bank ecology. In Ecology of soil seed banks. Edited by M.A. Leck, V.T. Parker, and R.L. Simpson. Academic Press, San Diego, CA. pp. 5366.

Belsky, A.J. 1986a. Revegetation of artificial disturbances in grasslands of the Serengeti National Park, Tanzania. I. Colonization of grazed and ungrazed plots. J. Ecol. 74: 419-437.

Belsky, A.J. 1986b. Revegetation of artificial disturbances in grasslands of the Serengeti National Park, Tanzania. II. Five years of successional change. J. Ecol. 74: 937-951.

Belsky, A.J. 1992. Effects of grazing, competition, disturbance and fire on species composition and diversity in grassland communities. J. Veg. Sci. 3: 187-200.

Bennington, C.C., and Thayne, W.V. 1994. Use and misuse of mixed model analysis of variance in ecological studies. Ecology 75: 717-722.

Bergelson, J., Newman J.A., and Floresroux E.M. 1993. Rates of weed spread in spatially heterogeneous environments. Ecology 74: 999-1101. 
Brokaw, N.V.L. 1985. Treefalls, regrowth, and community structure in tropical forests. In The ecology of natural disturbance and patch dynamics. Edited by S.T.A. Pickett and P.S. White. Academic Press, Orlando, FL. pp. 5369.

Bullock, J.M., Clear Hill, B., Dale, M.P., and Silvertown, J. 1994. An experimental study of the effects of sheep grazing on vegetation change in a species-poor grassland and the role of seedling recruitment into gaps. J. Appl. Ecol. 31: 493-507.

Bullock, J.M., Clear Hill, B., Silvertown, J., and Sutton, M. 1995. Gap colonization as a source of grassland community change: effects of gap size and grazing on the rate and mode of colonization by different species. Oikos 72: 273-282.

Burke, M.J.W. and Grime, J.P. 1996. An experimental study of plant community invasibility. Ecology 77: 776-790.

Campbell, C.S., Quinn, J.A., Cheplick, G.P. and Bell, T.J. 1984. Cleistogamy in grasses. Annu. Rev. Ecol. Syst. 14: 411-441.

Chambers, J.C. and MacMahon, J.A. 1994. A day in the life of a seed. Annu. Rev. Ecol. Syst. 25: 263-292.

Coffin, D.P., and Lauenroth, W.K. 1989. Small scale disturbances and successional dynamics in a shortgrass plant community: interactions of disturbance characteristics. Phytologia 67: 258-286.

Collins, S.L., and Glenn, S.M. 1988. Disturbance and community structure in North American prairies. In Diversity and pattern in plant communities. Edited by H.J. During, M.J.A. Werger, and J.H. Willems. SPB Academic Publishing, The Hague. pp. 131-143. 
Connell, J.H. 1978. Diversity in tropical rain forests and coral reefs. Science 199: $1302-1310$.

Connell, J.H., and Slatyer, R.O. 1977. Mechanisms of succession in natural communities and their role in community stability and organization. Am.

Nat. 111: 1119-1144.

Crampton, B. 1974. Grasses in California. University of California Press, Berkeley, CA.

Davis, R.M., and Cantlon, J E. 1969. Effect of size area open to colonization on species composition in early old-field succession. Bull. Torrey Bot. Club 96: 660-673.

Denslow, J.S. 1980. Gap partitioning among tropical rainforest trees. Biotropica 12 (supplement): 47-55.

Fenner, M. 1985. Seed Ecology. Chapman and Hall, London.

Fenner, M., editor. 1992. Seeds: The Ecology of Regeneration in Plant Communities. CAB International, Wallingford.

Goldberg, D.E., and Gross, K.L. 1988. Disturbance regimes of midsuccessional old fields. Ecology 69: 1677-1688.

Goldberg, D.E., and Werner, P.A. 1983. The effects of size of opening in vegetation and litter cover on seedling establishment of goldenrods (Solidago spp.). Oecologia 60: 149-155.

Gross, K.L. 1980. Colonization of Verbascum thapsus (mullein) of an old-field in Michigan: experiments on the effects of vegetation. J. Ecol. 68: 919-927.

Gross, K.L. 1990. A comparison of methods for estimating seed numbers in the soil. J. Ecol. 78: 1079-1093. 
Gross, K.L., and Werner, P.A. 1982. Colonizing abilities of "biennial" plant species in relation to ground cover: implications for their distributions in a successional sere. Ecology 63: 921-931.

Harper, J. 1977. Population Biology of Plants. Academic Press, London.

Hartshorn, G.S. 1980. Neotropical forest dynamics. Biotropica 12

(supplement): 23-30.

Heady, H.F. 1988. Valley grassland. In Terrestrial vegetation of California. New expanded edition. Edited by M.G. Barbour and J. Major. Wiley, New York, NY. pp. 491-514.

Heady, H.F., Bartolome, J.W., Pitt, M.D., Savelle, G.D., and Stroud, M.C. 1992. California prairie. In Ecosystems of the world 8A: natural grasslands. Edited by R.T. Coupland. Elsevier, Amsterdam. pp. 313-335.

Heady, H.F., Foin, T.C., Kektner, J.J., Taylor, D.W., Barbour, M.G., and Berry, W.J. 1988. Coastal prairie and northern coastal scrub. In Terrestrial vegetation of California. New expanded edition. Edited by M.G. Barbour and J. Major. Wiley, New York, NY. pp. 733-760.

Hickman, J.C., editor. 1993. The Jepson manual: higher plants of California. University of California Press, Berkeley, CA.

Hobbs, R.J., and Huenneke, L.F. 1992. Disturbance, diversity, and invasion: implications for conservation. Conserv. Biol. 6: 324-337.

Hobbs, R.J., and Mooney, H.A. 1985. Community and population dynamics of serpentine grassland annuals in relation to gopher disturbance. Oecologia 67: 342-351.

Johnson, S. 1979. The land-use history of the Coast Range Preserve, Mendocino County, California. M.A. thesis, San Francisco State University, San Francisco, CA. 
Kirk, R.E. 1982. Experimental design: procedures for the behavioural sciences. 2nd ed. Brooks/Cole Publishing Co., Monterey, CA.

Kotanen, P.M. 1994a. Revegetation of meadows disturbed by feral pigs (Sus scrofa L.) in Mendocino County, California. Ph.D. thesis, Department of Integrative Biology, University of California, Berkeley, CA.

Kotanen, P.M. 1994b. Effects of feral pigs on grasslands. Fremontia 22(1): 14-17.

Kotanen, P.M. 1995. Responses of vegetation to a changing regime of disturbance: effects of feral pigs in a Californian coastal prairie. Ecography 18: 190-199.

Kotanen, P.M. In press. Revegetation following soil disturbance in a California meadow: the role of propagule supply. Oecologia.

Lavorel, S., Lepart, J., Debussche, M., Lebreton, J-D, and Beffy, J-L. 1994. Small scale disturbances and the maintenance of species diversity in Mediterranean old fields. Oikos 70: 455-473.

McConnaughay, K.D.M., and Bazzaz, F.A. 1987. The relationship between gap size and performance of several colonizing annuals. Ecology 68: 411-416.

McConnaughay, K.D.M., and Bazzaz, F.A. 1990. Interactions among colonizing annuals: Is there an effect of gap size? Ecology 71: 1941-1951.

McIntyre, S., Lavorel, S., and Tremont, R.M. 1995. Plant life-history attributes: their relationship to disturbance response in herbaceous vegetation. J. Ecol. 83: 31-44.

Marks, P.L., and Mohler, C.L. 1985. Succession after elimination of buried seeds from a recently plowed field. Bull. Torrey Bot. Club 112: 376-382. Miller, T.E. 1982. Community diversity and interactions between the size and frequency of disturbance. Am. Nat. 120: 533-536. 
Paine, R.T., and Levin, S.A. 1981. Intertidal landscapes: disturbance and the dynamics of pattern. Ecol. Monogr. 51: 145-178.

Parish, R., and Turkington, R. 1990a. The influence of dung pats and molehills on pasture composition. Can. J. Bot. 68: 1698-1705.

Parish, R., and Turkington, R. 1990b. The colonization of dung pats and molehills in permanent pastures. Can. J. Bot. 68: 1706-1711.

Peart, D.R. 1989a. Species interactions in a successional grassland. I. Seed rain and seedling recruitment. J. Ecol. 77: 236-251.

Peart, D.R. 1989b. Species interactions in a successional grassland. II. Effects of canopy gaps, gopher mounds and grazing on colonization. J. Ecol. 77: 267289.

Phillips, D.L., and Shure, D.J. 1990. Patch-size effects on early succession in southern Appalachian forests. Ecology 71: 204-212.

Pickett, S.T.A., and White, P.S., editors. 1985. The ecology of natural disturbance and patch dynamics. Academic Press Inc., Orlando, FL.

Platt, W.J. 1975. The colonization and formation of equilibrium plant species associations on badger disturbances in a tall-grass prairie. Ecol. Monogr. 45: 285-305.

Platt, W.J., and Strong, D.R., editors. 1989. Special feature: gaps in forest ecology. Ecology 70: 535-576.

Platt, W.J., and Weis, I.M. 1977. Resource partitioning and competition within a guild of fugitive prairie plants. Am. Nat. 111: 479-513.

Rabinowitz, D., and Rapp, J.K. 1985. Colonization and establishment of Missouri prairie plants on artificial soil disturbances. II. Detecting smallscale plant-to-plant interactions and separating disturbance from resource provision. Am. J. Bot. 72: 1629-1634. 
Rapp, J.K., and Rabinowitz, D. 1985. Colonization and establishment of Missouri prairie plants on artificial soil disturbances. I. Dynamics of forb and graminoid seedlings and shoots. Am. J. Bot. 72: 1618-1628.

Reader, R.J., and Buck, J. 1991. Community response to experimental soil disturbance in a midsuccessional, abandoned pasture. Vegetatio 92: 151-159.

Runkle, J.R. 1982. Patterns of disturbance in some old-growth mesic forests of eastern North America. Ecology 63: 1533-1546.

Simberloff, D. 1988. The contribution of population and community biology to conservation science. Annu. Rev. Ecol. Syst. 19: 473-511.

Sims, P.L. 1988. Grasslands. In North American Terrestrial Vegetation. Edited by M.G.Barbour and W.D. Billings. Cambridge University Press, Cambridge. pp. 265-286.

Sokal, R.R. and Rohlf, F.J. 1981. Biometry. 2nd edition. W.H. Freeman and Company, New York, NY.

Sousa, W.P. 1979a. Disturbance in marine intertidal boulder fields: the nonequilibrium maintenance of species diversity. Ecology 60: 1225-1239.

Sousa, W.P. 1979b. Experimental investigations of disturbance and ecological succession in a rocky intertidal community. Ecol. Monogr. 49: 227-254.

Sousa, W.P. 1980. The responses of a community to disturbance: the importance of successional age and species’ life histories. Oecologia 45: 72-81.

Sousa, W.P. 1984a. The role of disturbance in natural communities. Annu. Rev. Ecol. Syst. 15: 353-391.

Sousa, W.P. 1984b. Intertidal mosaics: patch size, propagule availability, and spatially variable patterns of succession. Ecology 65: 1918-1935. 
Sousa, W.P. 1985. Disturbance and patch dynamics on rocky intertidal shores.

In The ecology of natural disturbance and patch dynamics. Edited by S.T.A.

Pickett and P.S. White. Academic Press, Orlando, FL. pp. 101-124.

Uhl, C., Clark, K., Dezzeo, N. and Maquirino, P. 1988. Vegetation dynamics in Amazonian treefall gaps. Ecology 69: 751-763.

Vogel, S. 1994. Life in Moving Fluids. 2nd ed. Princeton University Press, Princeton, NJ.

White, P.S. 1979. Pattern, process, and natural disturbance in vegetation. Bot.

Rev. 45: 229-299. 
Table 1. Dates on which the area $\times$ shape disturbance experiment was sampled. Bulbs were not sampled in 1991.

$\begin{array}{lll}\text { Year } & \text { Event } & \text { Date } \\ 1991 & \text { Establishment } & \text { February 23 - March } 9 \\ & \text { Sampling (bulbs) } & - \\ & \text { Sampling (graminoids + dicots) } & \text { June } 12-14 \\ 1992 & \text { Sampling (bulbs) } & \\ & \text { Sampling (graminoids }+ \text { dicots) } & \text { February 29 - March } 1 \\ & & \text { June } 11-12 \\ & & \\ & \text { Sampling (bulbs) } & \text { February } 13-15 \\ & \text { Sampling (graminoids }+ \text { dicots) } & \text { June } 12-14\end{array}$


Table 2. Graminoids occurring in disturbed plots (central quadrats only). Data represent mean (SEM) number of shoots $\mathrm{cm}^{-2}$. Also shown for each date are parametric part-whole correlations (Sokal and Rohlf 1981) relating the abundance of each taxon to the total abundance of its respective species group (perennial or annual graminoids). Sample size $=40$ plots on each date. Species codes are as follows: Dc = Danthonia californica, Lz = Luzula comosa (perennials); Jb = Juncus bufonius, Ai = Aira caryophyllea, $\mathrm{Bz}=$ Briza minor; $\mathrm{Vu}=$ Vulpia spp., $\mathrm{Bh}=$ Bromus hordaceus (annuals).

\begin{tabular}{|c|c|c|c|c|c|c|c|c|}
\hline Year & Parameter & Dc & $\mathrm{Lz}$ & $\mathrm{Jb}$ & $\mathrm{Ai} \dagger$ & $\mathrm{Bz}$ & $\mathrm{Vu}$ & $\mathrm{Bh}$ \\
\hline \multirow[t]{2}{*}{1991} & Mean(SEM) & $0.008(0.002)$ & $0.000(0.000)$ & $0.048(0.007)$ & $0.001(0.000)$ & $0.001(0.000)$ & $0.001(0.000)$ & $0.000(0.000)$ \\
\hline & Correlation (r) & $1.000 * *$ & 0.000 & $0.995^{* *}$ & -0.176 & 0.034 & $0.336^{*}$ & 0.000 \\
\hline \multirow[t]{2}{*}{1992} & Mean(SEM) & $0.096(0.011)$ & $0.042(0.011)$ & $0.149(0.022)$ & $0.010(0.003)$ & $0.011(0.004)$ & $0.008(0.003)$ & $0.008(0.003)$ \\
\hline & Correlation (r) & $0.657 * *$ & $0.728 * *$ & $0.934 * *$ & 0.102 & -0.136 & 0.174 & $0.363^{*}$ \\
\hline \multirow[t]{2}{*}{1993} & Mean(SEM) & $0.121(0.018)$ & $0.128(0.027)$ & $0.167(0.053)$ & $0.264(0.067)$ & $0.080(0.020)$ & $0.028(0.008)$ & $0.014(0.005)$ \\
\hline & Correlation (r) & $0.517^{* *}$ & $0.828 * *$ & $0.750 * *$ & $0.862 * *$ & -0.034 & -0.070 & 0.148 \\
\hline
\end{tabular}

† Rarely may include seedlings of similar annual graminoids. 
Table 3. Effects of disturbance area and shape on the abundance of each species group. Shown are the results of repeated-measures ANOVAs (SPF-pr.q fixed effects design: Kirk 1982). Data were log-transformed before analysis.

\begin{tabular}{|c|c|c|c|c|}
\hline Species Group & Factor & $\mathrm{df}$ & MS & $\mathrm{F}$ \\
\hline \multirow[t]{9}{*}{ Bulbs } & Shape & 1 & 0.452 & $5.411 *$ \\
\hline & Size & 3 & 0.405 & $4.847^{* *}$ \\
\hline & Shape $\times$ Size & 3 & 0.230 & 2.751 \\
\hline & Plot(Shape $\times$ Size $) \dagger$ & 32 & 0.084 & \\
\hline & Year & 1 & 0.845 & $11.524^{* *}$ \\
\hline & Year $\times$ Shape & 1 & 0.046 & 0.624 \\
\hline & Year $\times$ Size & 3 & 0.136 & 1.854 \\
\hline & Year $\times$ Shape $\times$ Size & 3 & 0.077 & 1.043 \\
\hline & Year $\times$ Plot $($ Shape $\times$ Size $) ~ \dagger$ & 32 & 0.073 & \\
\hline \multirow[t]{9}{*}{ Perennial graminoids } & Shape & 1 & 0.043 & 0.394 \\
\hline & Size & 3 & 0.713 & $6.540 * *$ \\
\hline & Shape $\times$ Size & 3 & 0.140 & 1.285 \\
\hline & Plot $($ Shape $\times$ Size $) \dagger$ & 32 & 0.109 & \\
\hline & Year & 2 & 13.714 & $239.595 * * *$ \\
\hline & Year $\times$ Shape & 2 & 0.021 & 0.368 \\
\hline & Year $\times$ Size & 6 & 0.135 & $2.355^{*}$ \\
\hline & Year $\times$ Shape $\times$ Size & 6 & 0.087 & 1.526 \\
\hline & Year $\times$ Plot $($ Shape $\times$ Size $) \dagger$ & 64 & 0.057 & \\
\hline
\end{tabular}


Table 3. Continued.

\begin{tabular}{|c|c|c|c|c|}
\hline Species Group & Factor & $\mathrm{df}$ & MS & $\mathrm{F}$ \\
\hline \multirow[t]{9}{*}{ Annual graminoids } & Shape & 1 & $<0.001$ & $<0.001$ \\
\hline & Size & 3 & 0.154 & 0.806 \\
\hline & Shape $\times$ Size & 3 & 0.113 & 0.589 \\
\hline & Plot $($ Shape $\times$ Size $) \dagger$ & 32 & 0.192 & \\
\hline & Year & 2 & 8.186 & $110.351^{* * *}$ \\
\hline & Year $\times$ Shape & 2 & 0.106 & 1.424 \\
\hline & Year $\times$ Size & 6 & 0.356 & $4.796 * * *$ \\
\hline & Year $\times$ Shape $\times$ Size & 6 & 0.020 & 0.274 \\
\hline & Year $\times$ Plot $($ Shape $\times$ Size $) \dagger$ & 64 & 0.0742 & \\
\hline \multirow[t]{9}{*}{ Dicots } & Shape & 1 & 0.010 & 0.081 \\
\hline & Size & 3 & 0.563 & $4.607^{* *}$ \\
\hline & Shape $\times$ Size & 3 & 0.122 & 1.000 \\
\hline & Plot $($ Shape $\times$ Size $) \dagger$ & 32 & 0.122 & \\
\hline & Year & 2 & 1.634 & $27.425^{* * *}$ \\
\hline & Year $\times$ Shape & 2 & 0.004 & 0.068 \\
\hline & Year $\times$ Size & 6 & 0.149 & $2.496^{*}$ \\
\hline & Year $\times$ Shape $\times$ Size & 6 & 0.123 & 2.061 \\
\hline & Year $\times$ Plot $($ Shape $\times$ Size $) \dagger$ & 64 & 0.060 & \\
\hline
\end{tabular}


Table 4. Effects of disturbance area and shape on the abundance of Juncus bufonius and annual grasses. Shown are the results of repeated-measures ANOVAs (SPF-pr.q fixed effects design: Kirk 1982). Data were log-transformed before analysis.

$\begin{array}{llrll}\text { Group } & \text { Factor } & \text { df } & \text { MS } & \text { F } \\ & & & & \\ \text { Juncus bufonius } & \text { Shape } & 1 & 0.513 & 1.761 \\ & \text { Size } & 3 & 2.224 & 7.636^{* * *} \\ & \text { Shape } \times \text { Size } & 3 & 0.216 & 0.742 \\ & \text { Plot(Shape } \times \text { Size }) \dagger & 32 & 0.291 & \\ & \text { Year } & 2 & 1.235 & 11.804^{* * *} \\ & \text { Year } \times \text { Shape } & 2 & 0.005 & 0.043 \\ & \text { Year } \times \text { Size } & 6 & 1.035 & 9.892^{* * *} \\ & \text { Year } \times \text { Shape } \times \text { Size } & 6 & 0.126 & 1.205 \\ & \text { Year } \times \text { Plot(Shape } \times \text { Size }) \dagger & 64 & 0.105 & \end{array}$


Table 4. Continued.

\begin{tabular}{|c|c|c|c|c|}
\hline Group & Factor & $\mathrm{df}$ & MS & $\mathrm{F}$ \\
\hline \multirow[t]{9}{*}{ Annual grasses } & Shape & 1 & 1.133 & $8.094 * *$ \\
\hline & Size & 3 & 1.848 & $13.206 * * *$ \\
\hline & Shape $\times$ Size & 3 & 0.188 & 1.344 \\
\hline & Plot(Shape $\times$ Size $) \dagger$ & 32 & 0.140 & \\
\hline & Year & 2 & 16.986 & $225.253 * * *$ \\
\hline & Year $\times$ Shape & 2 & 0.170 & 2.250 \\
\hline & Year $\times$ Size & 6 & 0.359 & $4.760 * * *$ \\
\hline & Year $\times$ Shape $\times$ Size & 6 & 0.087 & 1.149 \\
\hline & Year $\times$ Plot $($ Shape $\times$ Size $) \dagger$ & 64 & 0.075 & \\
\hline$\dagger$ error terms & & & & \\
\hline
\end{tabular}


Table 5. Depth distribution of species represented in soil cores. Data represent mean (SEM) bulbs or seedlings $\mathrm{cm}^{-2}$. Species codes for seedlings are as follows: Dc= Danthonia californica, Lz = Luzula comosa (perennials), Jb = Juncus bufonius, Ai = Aira caryophyllea, $\mathrm{Br}=$ Bromus spp. (annuals), Dicots = all dicot seedlings. Sample size: $\mathrm{n}=39$ per cell.

$\begin{array}{ccccccccc}\text { Depth (cm) } & \text { Bulbs } & \text { Dc } & \text { Lz } & \mathrm{Jb} & \mathrm{Ai} & \mathrm{Br} & \text { Dicots } & \text { Total Seeds } \\ 0-2 & 0.370(0.056) & 0.017(0.009) & 0.203(0.044) & 0.024(0.009) & 0.145(0.045) & 0.014(0.006) & 0.007(0.005) & 0.405(0.082) \\ 2-4 & 0.196(0.030) & 0.002(0.002) & 0.002(0.002) & 0.057(0.011) & 0.119(0.095) & 0.000(0.000) & 0.005(0.003) & 0.186(0.094) \\ 4-6 & 0.048(0.016) & 0.002(0.002) & 0.000(0.000) & 0.029(0.008) & 0.021(0.009) & 0.000(0.000) & 0.000(0.000) & 0.052(0.012) \\ 8-10 & 0.019(0.013) & 0.000(0.000) & 0.000(0.000) & 0.045(0.010) & 0.031(0.018) & 0.000(0.000) & 0.000(0.000) & 0.076(0.020)\end{array}$




\section{Figure Captions}

Fig. 1. Mean (+SEM) numbers of shoots produced by bulbs, annual graminoids, and perennial graminoids. From left to right, treatments are undisturbed controls ( ), circular excavations ( ) with areas of 156, 625, 2500, and $10000 \mathrm{~cm}^{2}$, and rectangular

excavations $(\quad$ ) of the same areas. Sample size $=45$ plots on each date. Bulbs were not sampled in 1991.

Fig. 2. Mean (+SEM) numbers of shoots produced by annual grasses and Juncus bufonius in controls ( ), circular excavations ( ), and rectangular excavations ( ). Order of treatments, sample sizes are as in Fig. 1.

Fig. 3. Mean (+SEM) numbers of shoots at centres ( $\quad$ ) and edges $(\quad$ ) of those plots $\geq$ $2500 \mathrm{~cm}^{2}$ in area; "*" indicates a significant difference (Bonferroni $\mathrm{p}<0.05$ ). Sample size =19-20 plots per bar. Bulbs were not sampled in 1991 .

Fig. 4. Mean (+ SEM) seeds and bulbs detected in soil cores and seed traps. Sample size = 4-5 per date (soil cores) and 8-10 per date (seed traps). 